\section{Spatial Dynamics And Risks Analysis Of Lowlands Degradation Potential Around Of Nakanbé-Dem Sub- Watershed In Center-Nord Of Burkina Faso (West Africa): Through Multi-Date Study And Satellite Tele-Analysis}

Submitted: 19 May 2020

Accepted: 26 November 2020

Published: 30 November 2020

Corresponding author:

Adama Ilboudo

DOI: $10.19044 /$ esj.2020.v16n33p122

(c) Copyright 2020 Ilboudo et al.

Distributed under Creative Commons BY-NC-ND 4.0 OPEN ACCES

\section{Cite as:}

Ilboudo A, S Sawadogo, S. Soulama, E. Hien, Z. Prosper (2020). Spatial Dynamics And Risks Analysis Of Lowlands Degradation Potential Around Of Nakanbé-Dem Sub-Watershed In Center-Nord Of Burkina Faso (West Africa): Through Multi-Date Study And Satellite TeleAnalysis. European Scientific Journal, ESJ, 16 (33), 122. https://doi.org/10.19044/esj.2020.v16n33p122

\begin{abstract}
Watershed degradation is a key issue for environmental change in the Sahel region and causes an unprecedented threat to the lowlands watershed and the livelihood of local people. This study analyzes the spatial dynamics and degradation risks of Nakanbé-Dem sub-watershed lowlands'potential. The study combines lowlands plants species assessment and digital processing. Lowlands spatiotemporal dynamics were assayed from landsat images of 1986, 1996, 2006 and 2016. Vegetation data and soil physical and chemical parameters allowed to characterize lowlands degradation states. Lowlands degradation risk assessment is based on flora analysis and remote sensing indices (Normalized Difference Vegetation Index, Normalized Difference Water Index, slope values and water accumulation zones). Spatio-temporal dynamics analysis between 1986 and 2016 showed a continuous degradation of Nakanbé-Dem lowlands potential. The coverage of farming land increased from 31 to $51 \%$ compared to the total lowland potential of 43320 ha. The riparian formations have decreased by $4.11 \%$ in the same period. As concerns the lowland beds, their coverage rate has continuously decreased from $24 \%$ in 1986 to $7.79 \%$ in 2016. The coverage rate of water bodies has not kept a linear evolution. It went from 2.27 to $2.62 \%$, a slight increase of $0.35 \%$. Soil and flora samples were taken from the three lowland geomorphological subunits: glacis, hillside and the central
\end{abstract}


zone. Soil analyze concerned the following parameters: useful water content, saturation rate, carbon, nitrogen, potassium and bulk density. Flora parameters analyzed are: woody cover, density of regeneration individuals, tree density, quadratic diameter, tree height, ligneous plants species richness, herbaceous species richness. These different measurements have been taken on the glacis, hillside and central zone. Flora and soils analysis showed difference in lowlands topographic structures. Unlike hillside and glacis, their central zone is less degraded. It is characterized by an average specific richness of woody plants about $3.43 \%$ against $3.13 \%$ for hillsides and 2. $44 \%$ for glacis. Tree average density (129.29 in/ha), the number of trees large diameter (118. $55 \mathrm{in} / \mathrm{ha}$ ) and woody cover $(61.79 \%)$ are higher in the central zone than on the hillsides and glacis. From Pedological aspects, central zone is characterized by a concentration great of organic matter $(1.49 \%)$ (great rate of carbon and nitrogen) against 0.89 for glacis and 0.90 for hillsides. The useful water content (19.75\%) and the saturation rate (64.85) in the central zone are great. These values are low on the glacis (9.36 and 63,77) and hillsides (12.17 and 59.66). In the current context of persistent climatic pressure, the conquering of new farms will accelerate the growth of cropped acreages and increase the degradation risk of lowlands' potential. Lowlands' dynamic apprehension can serve as a basis of development and endogenous programs implementation to restore sub-watershed lowland' potential..

Subject: Environmental and earth science

Keywords: Nakanbé-Dem, SubWatershed, Lowlands, Ecological, Degradation 


\section{Introduction}

The West African region covering approximately one-quarter of the African continent is endowed with rich watersheds whose lowlands provide ecosystem goods and services to many local communities, including farmers (Oyebande and Odunuga, 2010); (Jalloh et al., 2012); (Gessner et al., 2015). Among goods provided, agricultural production represents one of the predominant livelihood activities along livestock production systems related to cattle, goats, and sheep (Danso et al., 2018). Ecosystem services provided by watersheds help purify groundwater, reduce erosion and control floods. They also include carbon sequestration, soil stabilization, habitats for recreational activities such as ecotourism and climate change mitigation. Wood and non-wood forest products (NTFPs) are also sources of health and cultural uses (Ola and Benjamin, 2019). Formerly reserved for pastures and farming, the plains are now the areas most coveted by farmers whose production activities are more secure (Oloukoi et al.); (2006, Souberou et al., 2018). In the recent decade, there has been an increased use of lowland areas to the point of restrict land available to other livelihood activities around the lowland (Souberou et al., 2017). One of the consequences of such uncontrolled use is that the riparian formations that characterize the lowlands are gradually destroyed (Fontès and Guinko, 1995; Mahamane et al., 2007); (Khoudia et al., 2014) driven by anthropogenic pressure and environmental degradation driven by climate variability (Robert, 2011); (Souberou et al., 2017). Agricultural losses, recurrent food crises, water scarcity and extreme flooding around watersheds are among the common vulnerability factors affecting farmers' livelihoods in the lowlands (Ariori and Ozer, 2005). Regular monitoring and spatial surveillance of natural resources degradation in watersheds helps overcome the vulnerability factors affecting the ability of the lowlands to continue provide goods and services to local farmers. It also improving conditions and local community's livelihoods. Remote sensing tools have been used successfully to map and monitor spatio-temporal drivers of watershed resource degradation (Twumasi and Merem, 2007). The latter has used remote sensing and GIS in the analysis of the ecosystems decline along the River Niger watershed in Mali and Niger. They found that the potential of the river was declining because of several factors: inadequate policy on land and water management, bad practices agricultural, population growth and variability in climate affecting the watershed ecosystem.

Elsewhere, the progress made in cartographic techniques have contributed to acquiring precise knowledge of the factors driving land degradation in terms of $: \mathrm{i}$ ) the degradation process and speed by using multidate analysis of satellite images (Souberou et al., 2017), and ii) analyzing the challenges affecting the ecosystems dynamics and the driving factors of 
ecosystems change by combining remote sensing with field data (Geymen and Baz, 2008).

However, use such tools is not throughout the western African countries such as Burkina Faso where policymakers lack sufficient knowledged on the dynamics of watershed degradation.

Burkina Faso covering an area of $274000 \mathrm{~km} 2$, is divided into three agroecological zones: the Sahelian zone, the North Sudanian zone and the South Sahelian zone. The Sahelian zone, composed by the strict Sahelian zone and the sub-Sahelian zone, is endowed with rich watersheds whose lowlands provide goods and ecosystem services to many local communities, including farmers. Agriculture, livestock and fishing around the banks of lakes and wetlands are among the key livelihood activities upon which local communities depend strongly on. Such dependency has driven competition over banks of lakes and lowlands. More importantly, and over the last decades, the rooted, intermediate and immediate causes of environmental degradation have contributed to weakening lowland ecosystem functions and watersheds integrity (Biot et al., 1995).

The root causes of watershed resources degradation relate to anthropogenic pressure, vulnerability factors linked to weather conditions and irregular rainfall regimes. On the contrary, the intermediate causes are linked to land tenure insecurity, unsustainable agricultural practices and overgrazing. The immediate threats are loss of soil nutrients, loss of organic carbon, unavailability of groundwater, and wind erosion

The root causes of watershed resources degradation relate to anthropogenic pressure, vulnerability factors linked to weather conditions and irregular rainfall regimes. The intermediate causes are linked to land tenure insecurity, unsustainable agricultural practices and overgrazing. The immediate threats are loss of soil nutrients, loss of organic carbon, unavailability of groundwater, and wind erosion

Responding to the rooted, intermediate, and immediate causes of watershed degradation, several initiatives related to national strategy and action plan, programs, policy and institutions on sustainable land use management (including watershed resources) have been implemented around 2000. The Burkinabé State has undertaken a policy of constructing water reservoirs to improve the availability of water resources (CR-CN, 2015). In 2003, a national strategy and action plan for integrated water resources management have been adopted and implemented to enhance watershed resources management. Another key program includes that of the Global Environmental Facility (GEF) which has approved a pilot partnership program for sustainable land management in the country. At the policy and institutional level, a watershed management policy has been established in 2001 while an agency of water resources management has been established to deal with water 
management issues along with the Permanent Secretariat for Integrated Water Resources Management (SP / IWRM).

Despite the implementation of all these initiatives for lowland resources management, policymakers still lack enough knowledge on the watershed resources management and progress has remained vague, especially around the Nakanbé-Dem sub-watershed in Center-Nord of Burkina Faso (West Africa) where the issue of the decline of the watershed potential is still acute.

This study aims to assess the spatial and temporal dynamics and driving factors of lowland degradation around the Nakanbé-Dem watershed using remote sensing tools. The inventory of lowlands using remote sensing data has been the subject of several research works in recent years. Lowlands in intertropical regions are "areas of the landscape, with a flat or concave bottom, located at the head of the hydrographic network, without watercourse or with a little marked minor bed (Hounkpetin, 2003). (Chabi et al.,2010); (Souberou et al. (2016) define lowlands in Benin as areas of depression located upstream of the hydrographic network and whose area is less than or equal to 25 ha. In Burkina Faso, lowlands are drainage axes and localized depressions of glacis with hydromorphic soils, dense shrub savannah. They are landscape units spread over the alluvial plains, often elongated in shape and flooded during the rainy season (Lamourdia, 2000). The estimate of lowland potential takes into account three identification criteria including slope, NDVI and area less than or equal to 25 ha (Chabi et al., 2010). However, the lowland potential of the Nakanbé-Dem includes all water accumulation areas whose slopes are less than or equal to $2 \%$ in which the water stagnates for a certain time before any infiltration or flow in the courtyards. temporary water nearby.

In Nakanbé-Dem sub-watershed, the lowland, whatever its size, is a wetland of local or regional agricultural importance. The lowland represents a means of resistance face of climatic change, in particular the current rainfall deficit. The main advantage of lowlands is to concentrate surface and subterranean flows, thus favoring varieties cultivation which require more water, such as maize and rice. The lowlands are real places of diversification of production where peasants, farmers and breeders exploited fodder, woody and fruit resources, as well as the plants used in pharmacopoeia and crafts. The lowlands are used as places of worship, fishing and watering animals in the dry season. These wetlands are strategic sites both for socio-economic development, food security and improvement of the living conditions of populations (Thiombiano, 2000).

However, serious threats risk preventing the Nakanbé-Dem lowlands to perform their socio-economic and environmental functions. Indeed, the rainfall decrease in Burkina Faso will cause a change in the health of lowland ecosystems. The strong tendency to increase the Nakanbé-Dem sub-watershed 
population (DREP / CN 2017) will lead to an increase in the conquest of new production lands. The uncontrolled installation of peasants in the lowlands will constitute a significant risk of degradation given the fragility of the environment. This situation will maintain the persistence of agricultural practices such as slash-and-burn, excessive logging, overgrazing, quarries in the lowlands. Lowland soils being poor in organic matter (low nitrogen and phosphorous contents) consequently have very little developed biological activity. These soils are therefore very sensitive to these bad agricultural practices which will accelerate the degradation dynamics of the lowlands. Understanding these threats recommends better mapping of surface conditions and rigorous monitoring of environmental dynamics. Information on the process and the rate of degradation can be effectively captured by satellite remote analysis (Collado et al., 2002). Nakanbé-Dem sub-watershed has been very little concerned with the use of remote sensing techniques in mapping and monitoring environmental changes.

Thus, the objectives of this study are i) to map the spatial and temporal dynamics of lowland area in the Nakanbé-Dem sub-watershed (1986-2016) in terms of water bodies, lowland beds, crop fields, woodland savannah, and riparian areas, ii) to assess the relationships between the current indicators and risks of lowlands degradation and iii) to discuss the opportunity to overturn the risks of lowlands degradation in the Nakanbé-Dem sub-watershed.

\section{Study Zone}

The study concerns the lowland of the Nakanbé-Dem sub-watershed (Fig. 1) located between the provinces of Sanmatenga and Bam, and being administratively part of the Cente-Nord region of Burkina Faso. Covering an area of 165029 ha, it is one of the forty (40) sub-watershed of the Nakanbé water resources management area. It is distributed between longitudes $1^{\circ} 26 ' 30^{\prime \prime} \mathrm{W}$ and $0^{\circ} 57^{\prime} 43^{\prime} ' \mathrm{~W}$ and latitudes $13^{\circ} 58^{\prime} 58^{\prime}$ ' $\mathrm{N}$ and $13^{\circ} 31^{\prime} 48 \mathrm{~N}$. Study area is located in the Sahelo-Sudanian transition type with rainfall between 600 and $700 \mathrm{~mm}$ (Fontès and Guinko, 1995).This climate is characterized by a long dry season (November to May) and a short rainy season (June to October). It is marked by strong interannual irregularities in precipitation and a general downward trend. Average annual temperatures vary between 20 to $28{ }^{\circ} \mathrm{C}$ during the wet season and are very high in the dry season, 35 to $40^{\circ} \mathrm{C}$, favoring the drying of water points by evaporation (Da et al., 2008). According to (Ouédraogo et al.,1992) the geological coverage of the sub-watershed includes two main geological formations. The anteBirrimian composed of granitic formations and the Birimian essentially of volcano-sedimentary rocks (tuffs, lavas, associated sediments, neutral to basic metavolcanites). The Birimian hills constitute the framework of the model of the study area. The geomorphological landscape is organized from the residual 
reliefs to the lowland which constitute preferential zones for the accumulation of runoff descending from the hillsides of the neighboring hills.

On these geomorphological units, five soil classes are developed, namely, raw mineral soils, poorly developed soils, browned soils, soils with iron and / or manganese sesquioxides and hydromorphic soils (CPCS, 1967).These soils support degraded plant formations mainly composed of parkland savannahs in which gallery forests have almost disappeared. The riparian formations are in the form of a more or less narrow cordon of vegetation, which occurs along temporary rivers. The thin vegetated strip is mainly dominated by Anogeissus leiocarpa (DC.) Guill. \& Per, Acacia seyal Del. and Mitragyna inermis (Willd.) Kuntze, for the longest flooded parts (Da et al., 2008).

Over the past few decades, the Nakanbé-Dem sub-watershed has experienced a sharp decrease in rainfall, which is superimposed on anthropogenic pressures and overcrowding.

Degradation is largely due to climatic variability and degradation of the vegetation cover. The causes are both natural and anthropogenic. The main cause of degradation mentioned is drought, with high wind. Then come the excessive cutting of wood, harmful agricultural and pastoral practices (Da et al., 2008). This double anthropogenic and climatic pressure has contributed to the reduction of plant cover and the extension of crop fields (Hamma et al., 2000) ; (Ibrahim, 2013). To cope with the population's water needs and climatic hazards, the Burkinabé State has initiated a policy of creating water reservoirs with the help of non-governmental organizations operating in the country. This slightly increased a relative abundance of water bodies in the Center-North region (MR-CN, 2011, CR-CN, 2015). Nakanbé-Dem population is characterized by a growth of $2.6 \%$ on average between the 1996 census and 2006. It is thus estimated at 1593214 inhabitants in 2016 and will reach 1787082 in 2020. Agriculture is still extensive and dominated by manual field work. It is practiced cumulatively with animal husbandry, which constitutes the second major activity (INSD, 2009); (DREP/CN, 2017). The population of sub-watershed, is always in search of fertile land, and actively intervenes in the development of the lowlands constituting a palliative to climatic variability. Farmers are developing some adaptation initiatives. The most demanding crops are placed on geomorphologic units of good fertility such as lowlands. On silty or clayey soils, farmers cultivate millet, sesame, rice, potatoes, calabash and sorghum when the clay content is high. (DREP / CN, 2017). "Zai" and "demi-moons" techniques are also development initiatives that peasants apply on the lowlands glacis. They combine these techniques by adding a few handfuls of manure. On the hillsides, the peasants use stone bunds or grass strips to stabilize soils against water erosion. They place earthen bunds in central lowland areas (Da et al., 2008). However, 
lowlands famers are not well organized. They are not sufficiently trained on lowland protection techniques. Thus, the gullies around the lowlands are not well treated. In addition, there is a visible lack of a sustainable plan for environmental restoration. Indeed, there is no policy of fertilization and amendment of lowland soils. No tree planting action is visible so the land pressure is increasing (Bandré and Da, 2004).

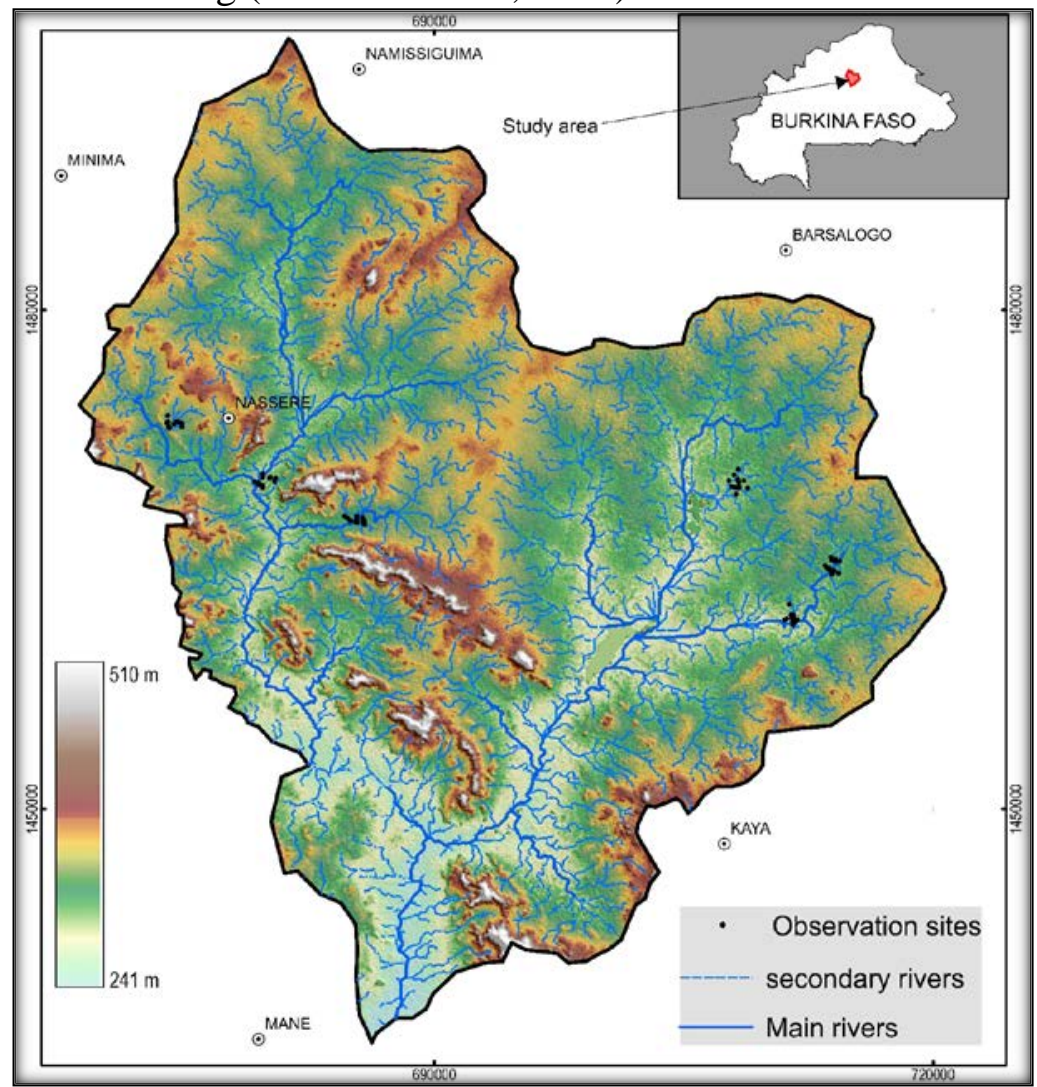

Figure 1: Location map of the Nakanbé-Dem sub-watershed area.

\section{Data and methods}

Remote sensing tools are relevant for evaluating lowlands' potential and their dynamics degradations. Supported by soil and vegetation measurements, remote sensing can provide information on lowlands degradation risks.

\section{Satellite imagery}

The identification of the lowland potential was based on the superimposition of the NDVI and NDWI values calculated from Landsat images (table 1) and those of the slopes and water accumulation zones extracted from the digital processing of the $30 \mathrm{~m}$ resolution Landsat ASTEM 
DEM image. The spectral range of TM and MSS sensors on Landsat platforms allows good identification of elements of the landscape (Salovaara et al., 2005); (Oszwald et al., 2007).

Table 1: specific characteristics of the different types of Landsat images. (Source:

http://eoedu.belspo.be/fr/satellites/landsat.htm)

\begin{tabular}{|c|c|c|c|c|}
\hline Years considered & Types of sensor & Years of acquisition & Number of bands & Bands used (NDVI,NDWI) \\
\hline \multirow[t]{4}{*}{1986} & Landsat5 MSS & $18 / 11 /$ & 1 (Blue) & 2 et 4 \\
\hline & & & 2 (Green) & \\
\hline & & & 3 ( Red) & \\
\hline & & & 4 (Near-infrared) & \\
\hline \multirow[t]{7}{*}{1996} & Landsat5 TM & $29 / 11 /$ & 1 (Blue) & 3 et 4 \\
\hline & & & 2 (Green) & \\
\hline & & & 3 ( Red) & \\
\hline & & & 4 (Near-infrared) & \\
\hline & & & 5 (Near-infrared 1) & \\
\hline & & & 6 (Thermal InfraRed) & \\
\hline & & & 7 (Short Wave InfraRed) & \\
\hline \multirow[t]{7}{*}{2006} & Landsat5 TM & $25 / 11 /$ & 1 (Blue) & 3 et 4 \\
\hline & & & 2 (Green) & \\
\hline & & & 3 ( Red) & \\
\hline & & & 4 (Near-infrared) & \\
\hline & & & 5 (Near-infrared 1) & \\
\hline & & & 6 (Thermal InfraRed) & \\
\hline & & & 7 (Short Wave InfraRed) & \\
\hline \multirow[t]{12}{*}{2016} & Landsat8 OLI TIRS & 23/11/ & 1 (Blue) & 4 et 5 \\
\hline & & & 2 (Green) & \\
\hline & & & 3 ( Red) & \\
\hline & & & 4 (Near-infrared) & \\
\hline & & & 5 (Near-infrared 1) & \\
\hline & & & 6 (Thermal InfraRed) & \\
\hline & & & 7 (Short Wave InfraRed 2) & \\
\hline & & & 8 (Panchromatic) & \\
\hline & & & 9 (Cirrus) & \\
\hline & & & 10 (Short Wave InfraRed) & \\
\hline & & & 11 (Short Wave InfraRed) & \\
\hline & & & 12 (BQA) & \\
\hline
\end{tabular}

The applied approach combined the phases of ground observations and analog and digital processing of satellite images.

The Landsat missions evolved from 1986 to 2016; which led us to look for band equivalences for Landsat 5 MSS (1986), Landsat 5 TM (1996), Landsat 5 TM (2006), Landsat 8 OLI (2016) in order to determine the different indices (Fig. 2). 


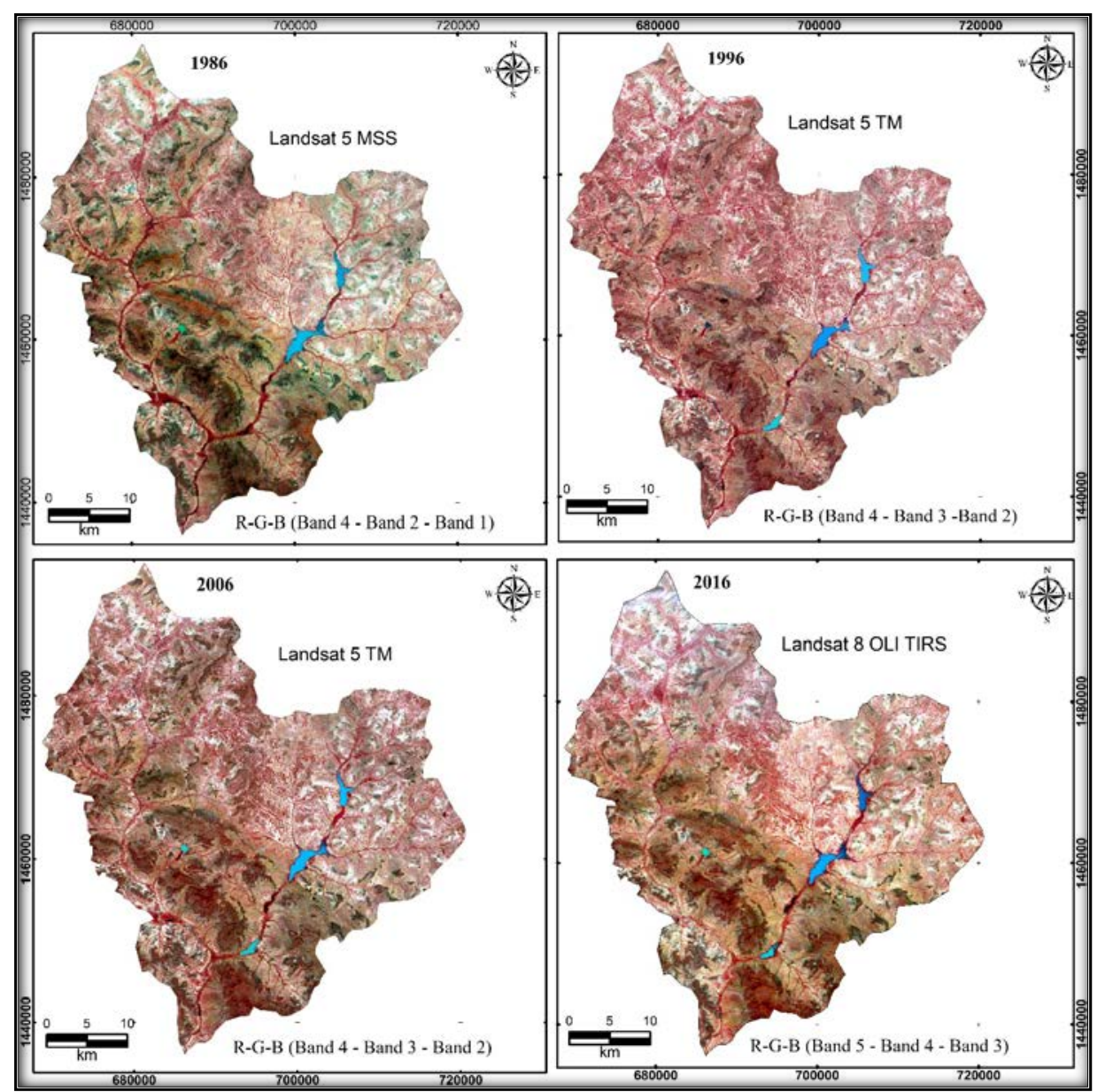

Figure 2: Comparative display of the three types of Landsat images used (MSS, TM and OLI -TIRS)

In order to maintain coherence in the spectral response of the different plant cover, the images were all acquired in the same month of November 1986, 1996, 2006, and 2016. At this time of the year, especially in this study area, the vegetation in the lowland contrasts with the rest of the landscape. The humidity which remains there always maintains a more flourished vegetation whose spectral response is clearly distinguished from other "anthropic" systems which were characterized at that time by a virtual absence of vegetation. Finally, the cloudiness of the images acquired during this period is greatly reduced and thus made it possible to limit atmospheric biases (Hountondji, 2008) ; (Oszwald et al., 2010). Radiometric corrections were applied to increase the readability of the images and to facilitate their interpretation. 


\section{Realization of the DTM and calculation of the slopes}

The Digital Terrain Model (DTM) is extracted from the ASTER DEM image with a resolution of $30 \mathrm{~m}$. This model made it possible to highlight the values of the slopes of the potential in the lowland of the study area. The distribution of these slopes into ten classes allowed to better define the areas of probable lowland. The ASTER DEM image is also used to identify potential areas of water accumulation, the superimposition of which with the values of the slopes made it possible to delimit the Nakanbé-Dem lowlands potential. The classification method directed using the maximum likelihood algorithm was used to classify the images according to the training areas identified by direct observation in the field. Four main units of occupation of this lowland potential have been defined to implement the classification: the riparian formation, the lowland bed, the crop fields and the water body. According to Bigot et al. (2005), the use of 4 to 6 land-use classes is very often sufficient to carry out a cartographic analysis of lowland ecosystems. The superposition of the values of accumulation zones to those of the slopes has allowed the extraction of lowlands' potential in the NakanbéDem sub-watershed. This approach is faster than the direct field approach for characterizing lowland agro-ecosystems, which requires more mobilization of material and human resources (Andriesse et al., 1994).

The lowlands potential of the Nakanbé-Dem sub-watershed was extracted from the intersection of the cartographic results of the slopes and the water accumulation areas.

\section{Determination of standardized indices}

The NDVI (Normalized Difference Vegetation Index) is a vegetation index based on a combination of reflectance's measured in red (RED) and near infrared (PIR). It is calculated according to the following formula: NDVI = (PIR-R) / (PIR + R) where PIR corresponds to the near infrared band and R that of red (Yoshida, 2005). The value of the NDVI of lowlands' potential in Nakanbé-Dem sub-watershed is between - 0.672 and 0.791 .

The projection of NDVI map showed that the value of NDVI <- 0.672 corresponds to spaces without vegetation such as water bodies and soils; moderate values ( 0.2 to 0.3 ) represent crop fields, while high values ( 0.5 to 0.8 ) indicate riparian formations.

The NDWI (Normalized Difference Water Index) was used to detect soil moisture and water content in vegetation. The middle infrared spectral band is used in place of the red band. NDWI: (PIR-MIR) / (PIR + MIR) (Gao, 1996). The NDVI values and NDWI tent to analyze the spatio-temporal distribution of potential of the landscape units in lowlands (Kaplan and Avdan, 2017) ; (Souberou et al., 2017). 


\section{Ecological structure of lowlands}

Soil and vegetation data were collected using stratified random sampling according to topographical stages. A total of 11 plots were established in central zones; 18 in hillsides and 7 in glacis for data collection. Woody species were measured in plots of $50 \mathrm{~m}$ x $20 \mathrm{~m}$. Every woody species greater than $20 \mathrm{~cm}$ diameter at $130 \mathrm{~cm}$ height was identified and measured. Then sub-plots of $10 \mathrm{~m}$ x $10 \mathrm{~m}$ were used for herbaceous diversity sampling. Flora parameters analyzed were: woody cover, density of regeneration individuals, tree density, quadratic diameter, tree height, ligneous plants species richness, herbaceous species richness. These different measurements have been taken on the glacis, hillsides and Central zone. Inside each plot, soil samples were taken at depths of $0-30 \mathrm{~cm}$. The following soil parameters were analysis: useful water content, saturation rate, carbon, nitrogen, potassium and bulk density.

A canonical discriminant analysis by $\mathrm{R}$ software was used to discriminate the three zones of the lowlands (glacis, hillsides and central zone). This type of analysis allowed to perform a linear combination of all quantitative variables in order to discriminate between states. Canonical discriminant analysis has been used in ecological studies (Hountondji, 2008); (Soulama, 2016). Thus, the average of each parameter was calculated. Finally, taxon quantification parameters (abundance, dominance, basal area and frequency) were used to calculate the relative ecological importance of each woody species expressed by the Importance Value Index (IVI). The basal area (G) was the sum of the cross-sectional areas (in $\mathrm{m}^{2}$ ) of all individuals of a species with diameter at $20 \mathrm{~cm}$ above ground level of at least $5 \mathrm{~cm}$ and is reported per hectare. The IVI of a species was defined as the sum of its relative dominance, relative density, and relative frequency. The values of relative dominance, relative frequency and relative density vary between 0 to $100 \%$ and the IVI of the species varies from 0 to $300 \%$. For multi-stemmed individuals the diameter $\mathrm{d}$ was the quadratic sum of all the diameters of the stems of the individual measured. The diameter formula $\mathrm{d}$ was calculated as follows:

- $\quad \mathrm{d}=\left(\mathrm{ds} 1^{2}+\mathrm{ds} 2^{2}+\mathrm{ds} 3^{2} \ldots \ldots . . \mathrm{dsi}{ }^{2}\right)^{1 / 2}$

(3)

- $\quad$ Basal area $(G)=D^{2} 20 \frac{\pi}{4}$ where $D$ is the diameter of $20 \mathrm{~cm}$ above $5 \mathrm{~cm}$

(4)

- $\quad$ Relative dominance $(\mathrm{DR})=$

$\frac{\text { Species basal area }}{\text { Total basal area of all species }} \times 100$

- $\quad$ Relative density (Dr) $=\frac{\text { Species individual number }}{\text { Total individual number }} \times 100$

- $\quad$ Species frequency $(\mathrm{Fs})=\frac{\text { Plots number containing the species }}{\text { Plot total number }} \times 100$ 
- $\quad$ Relative frequency $(\mathrm{FR})=$

$$
\frac{\text { Species frequency }}{\text { Sum of all frequencies }} \times 100
$$

$\mathrm{IVI}=\mathrm{DR}+\mathrm{Dr}+\mathrm{FR}$

\section{Results And Discussion}

\section{Potential In The Lowlands Of The Nakanbé-Dem Sub-Watershed}

The Digital Terrain Model (DTM) showed the different topographical facets where rivers and in particular lowlands originate in the upstream part of the hydrographic network. The slopes generated in the study area varied from to more than $30 \%$. These values showed that the study area is hilly in places. This corroborates the results of (Da et al., 2008) who noted that Nakanbé-Dem relief is in the form of hills and steep slopes. These authors specified that depressions have developed on the outskirts of high reliefs between steep slopes $\left(>30^{\circ}\right)$ and slightly inclined glacis $\left(1\right.$ to $\left.5^{\circ}\right)$. The low resolution of the image $(30 \mathrm{~m})$ did not allow for individual mapping of the lowland, but it did allow the exhaustive potential of the lowland to be identified and listed. Covering an area of 43320 ha, the lowland potential represented 26.25\% of Nakanbé-Dem watershed area 165029 ha. It composed by all the lowlands with an area of more than 0.5 ha. Its occupation units experienced a regressive dynamic during the thirty years considered (Fig. 3).

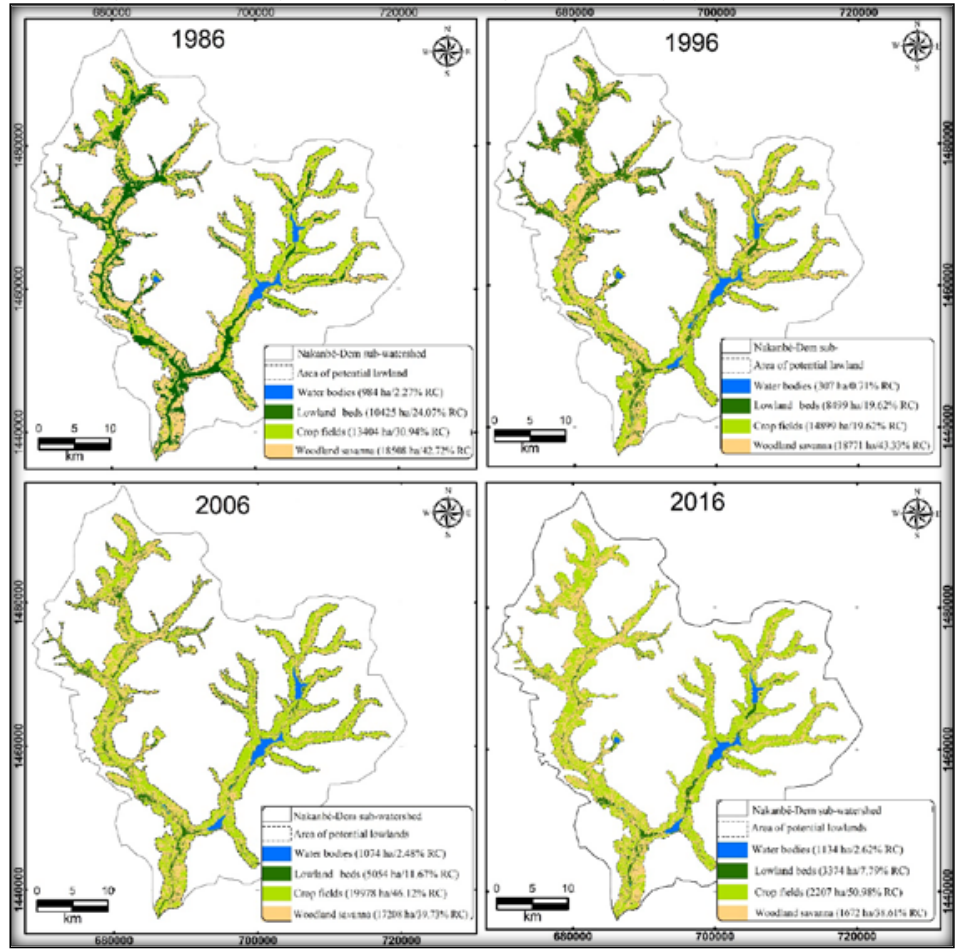

Figure 3: Dynamics of lowland potential landscape units.

Rc: Rate of coverage. 


\section{Comparative evolution of lowland potential landscape units - The lowland beds}

Between 1986 and 1996, the lowland beds knew a sharp decline from 24\% to $20 \%$ of the total lowland potential of Nakanbé-Dem (table 2). They were severely affected by the drought periods of the 1980 that experienced in Burkina Faso (Bandré et al, 2004) ;(MEE, 2001). Anthropogenic influence has accentuated environmental degradation and accelerated lowland areas (Ouédraogo, 2006) ; (Pierre, 2007). From 1996 to 2006, the regression of lowland beds continued. Its coverage rate has been reduced by $8 \%$, from $20 \%$ to 12\% (table 2). Between 2006 and 2016, the lowland beds maintained their continuous downward trend. During this period, their coverage rate decreased from $12 \%$ to $7.8 \%$.

Over these three decades, the lowlands beds have lost more than two thirds of their area, from $10.424 \%$ in 1986 to $3.374 \%$ in 2016, a reduction of 7.050 hectares. These results corroborate those of (Ouédraogo et al., 2010) who pointed out that in addition to anthropogenic pressure, the speed of regression in the lowlands is also due to the decrease in rainfall in Burkina Faso which caused a change in the state and appearance of ecosystems. These results confirm those of (Bambara et al.( 2013) who also discussed the combined effects of climate adverse circumstances and intense human activities to explain the drying up of rivers, the decline of groundwater and degradation of the vegetation cover in the lowland of the Sudano-Sahelian zone. According to (Kaboré et al.,2013), the pressure on these resources was so great that the cultivation of crops extends from the bank to the bed, which accentuates the silting up of shallow beds.

\section{o Crop fields}

Crop fields increased by 3.4\% between 1986 and 1996. Compared to the overall lowland potential, their coverage rate increased from 31\% to 34\% respectively (table 2). This extension corroborates the results of many authors (Ibrahim, 2013) ; (Da et al., 2008); (Ouédraogo et al., 2010) who were interested in the Center-North region. These authors noted that the destruction of plant cover and the loss of biodiversity have contributed to the extension of crop fields in the region. Between 1996 and 2006, the cultivated fields continued their progression passing respectively from $34 \%$ to $46 \%$ with an increase of 12\%. According to (Ouédraogo et al., 2010), the Center-North of Burkina Faso being particularly affected by the phenomenon of degradation, the soils there tend, under the effect of thunderstorms, to undergo surface reorganizations. Repeated droughts and unsuitable farming practices have led to the destruction of the plant cover which exposed the soil to wind and rain by accelerating its erosion (Hountondji, 2008); (Niang, 2006).

During the period from 2006 to 2016, the progression of crop fields became more remarkable. It went from 46 to $51 \%$ with a total increase of $4.9 \%$. The 
high demography that characterized the Sudano-Sahelian zone has led to pressure on agricultural land and caused soil degradation (Ouédraogo et al., 2010). During the thirty years considered, the farming areas only have expanded (Fig.4). They increased from 31\% in 1986 to 51\% in 2016, for a total of $20 \%$ increase. The average annual progression of degraded areas was $5 \%$. In terms of area, they increased from 13.404 to 22. 090 hectares, an increase of 8.686 hectares in 30 years.

Table 2: Spatial evolution of potential lowland areas

\begin{tabular}{|c|c|c|c|c|c|c|c|c|c|c|}
\hline \multirow[t]{2}{*}{ Period analysis } & \multicolumn{2}{|c|}{ 2iparian formations } & \multicolumn{2}{|c|}{ Lowland beds } & \multicolumn{2}{|c|}{ Cultivated fields } & \multicolumn{2}{|c|}{ Water bodies } & \multicolumn{2}{|c|}{ Coverage rate (CR) } \\
\hline & Cov.(ha) & CR (\%) & Cov.(ha) & CR (\%) & Cov.(ha) & CR (\%) & Cov.(ha) & CR (\%) & Cov.(ha) & CR (\%) \\
\hline 1986 & 18508 & 42,72 & 10424 & 24 & 13404 & 31 & 984 & 2,27 & 43320 & 100 \\
\hline 1996 & 18771 & 43,33 & 8500 & 20 & 14901 & 34 & 1148 & 2,65 & 43320 & 100 \\
\hline From 1986 to 1996 & 263 & 0,61 & -1924 & -4 & 1497 & 3,4 & 164 & 0,38 & - & - \\
\hline Appreciation & \multicolumn{2}{|c|}{ Progression } & \multicolumn{2}{|c|}{ Regression } & \multicolumn{2}{|c|}{ Progression } & \multicolumn{2}{|c|}{ Progression } & & \\
\hline 1996 & 18771 & 43,33 & 8500 & 20 & 14901 & 34 & 1148 & 2,65 & 43320 & 100 \\
\hline 2006 & 17208 & 39,73 & 5055 & 12 & 19983 & 46 & 1074 & 2,48 & 43320 & 100 \\
\hline From 1996 to 2006 & -1563 & $-3,6$ & -3445 & -8 & 5082 & 12 & -74 & $-0,17$ & - & - \\
\hline Appreciation & \multicolumn{2}{|c|}{ Regression } & \multicolumn{2}{|c|}{ Regression } & \multicolumn{2}{|c|}{ Progression } & \multicolumn{2}{|c|}{ Regression } & & \\
\hline 2006 & 17208 & 39,73 & 5055 & 12 & 19983 & 46 & 1074 & 2,48 & 43320 & 100 \\
\hline 2016 & 16722 & 38,61 & 3374 & 7,8 & 22090 & 51 & 1134 & 2,62 & 43320 & 100 \\
\hline From 2006 to 2016 & -486 & $-1,12$ & -1681 & -4 & 2107 & 4,9 & 60 & 0,14 & - & - \\
\hline Apprecialtion & \multicolumn{2}{|c|}{ Regression } & \multicolumn{2}{|c|}{ Regression } & \multicolumn{2}{|c|}{ Progression } & \multicolumn{2}{|c|}{ Progression } & & \\
\hline 1986 & 18508 & 42,72 & 10424 & 24 & 13404 & 31 & 984 & 2,27 & 43320 & 100 \\
\hline 2016 & 16722 & 38,61 & 3374 & 7,8 & 22090 & 51 & 1134 & 2,62 & 43320 & 100 \\
\hline From 1986 to 2016 & -1786 & $-4,11$ & -7050 & -16 & 8686 & 20 & 150 & 0,35 & - & - \\
\hline Appreciation final & \multicolumn{2}{|c|}{ Regression } & \multicolumn{2}{|c|}{ Regression } & Progres & ion & \multicolumn{2}{|c|}{ Progression } & & \\
\hline
\end{tabular}

\section{o The water bodies}

The surface area of water bodies increased slightly between 1986 and 1996. It increased respectively from $2.27 \%$ to $2.65 \%$ compared to the total lowland potential (table 2). This increase corresponded to a gradual improvement of the situation of water bodies, severely reduced during the dry period that preceded this decade. These results confirmed the analysis of (Ouédraogo et al., 2010) who noted that during the drought periods of the 1970, a deficit in rainfall was recorded and the filling rates of the reservoirs were very poor in northern Burkina Faso. Between 1996 and 2006, the coverage rate of water bodies started a regressive trend. It went down from 2.65 to $2.48 \%$, or $0.17 \%$ reduction. The main manifestations of climate change in Burkina Faso have been marked by a chronic drop in precipitation and a greater frequency of drought pockets (MEE, 2001).

On the other hand, from 2006 to 2016 the water bodies experienced a slight increase of $0.14 \%$, going from $2.48 \%$ to $2.62 \%$ (table 2 ). This increase is explained by the creation of water reservoirs in certain watersheds in the north of the country to cope with the increasing population increase (DREP/CN, 2017) and the climatic hazards (Nébié, 2018). Around 1985, the Burkinabé State began a policy of building water reservoirs with the help of non-governmental organizations operating in the country (CR-CN, 2015). This has resulted in a relative abundance of water bodies in the center-Nord region (MR-CN, 2011). 
The coverage rate of water bodies between 1986 and 2016 did not keep a linear evolution, but slightly progressive overall. It went from 2.27 to $2.62 \%$, a slight increase of $0.35 \%$.

\section{- Riparian pattern}

Riparian pattern increased by $0.61 \%$ between 1986 and 1996. From $42.72 \%$, its coverage rate increased to $43.33 \%$ (table 2). This decade which followed the great periods of drought knew a slight return to good environmental conditions. From 1996 to 2006, riparian pattern declined. Its coverage rate increased from $43.33 \%$ to $39.73 \%$. This regression is explained by the increasing land pressure (DREP/CN, 2017) which was manifested by the fact that everywhere, even the sites that were once abandoned, are starting to be cultivated.

During the period from 2006 to 2016, riparian pattern maintained its downward trend, going from 39.73\% to 38.61\%. From 1986 to 2016, the development of riparian pattern was regressive overall. Its coverage rate fell from 42.72 to $38.61 \%$, for a total of $4.11 \%$ reduction. Anthropogenic factors have put pressure on lowlands ecosystems. Population growth and land degradation have led the population to make more use of lowlands. In Sahelian countries, the lowlands have undergone an anthropic pressure with climatic variability. They have suffered from degradation of the hillsides drying of the water, disappearance and degradation of the plant cover (Souberou et al., 2017).

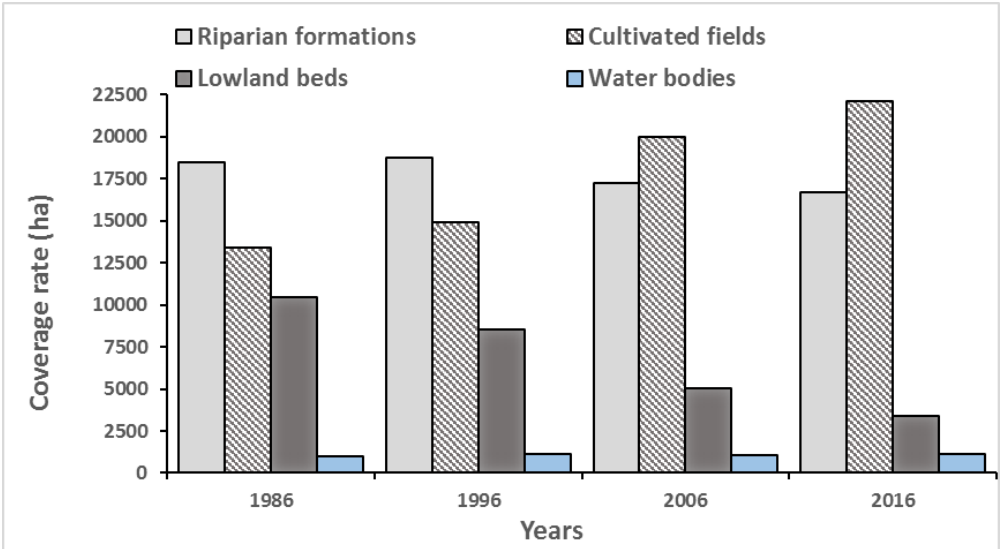

Figure 4: Comparative evolution of landscape units of the shallow potential

\section{Current indicators and risks of degradation of Nakanbé-Dem lowlands}

Figure 5 showed canonical discriminant analysis of the topographical effect on vegetation and soil parameters. This analysis showed a difference between lowland's central zone, hillsides ant glacis. 
Axes 1 and 2 explained 100\% of the explained variance. Axis 1 separated the central zone from the glacis and the hillsides. While axis 2 separated the glacis from the hillsides.

From Pedological aspects, central zone is characterized by a concentration great of organic matter (1.49\%) (great rate of carbon and nitrogen) against 0.89 for glacis and 0.90 for hillsides. The useful water content $(19.75 \%)$ and the rate of saturation (64.85) in the central zone are great. These values are low on the glacis (9.36 and 63.77) and on the hillsides (12.17 and 59.66).

Flora and soils analysis (Fig. 5) showed differences in lowlands topographic structures. Unlike hillsides and glacis, their central zone is less degraded. It is characterized by an average specific richness of woody plants about 3.43\% against $3.13 \%$ for the hillsides and $2.44 \%$ for the glacis. Tree average density (129.29 in/ha), the number of trees large diameter (118. 55 in/ha) and woody cover (61.79 \%) are higher in the central zone than on the hillsides and glacis. The fairly long presence of water explained the good behavior of plants in this compartment. In this central zone, the organic matter content was great because water drains soil nutrients and granulometric elements. Plants that took advantage of this fertility grew well (Sambaré et al., 2010). Rate saturation was particularly great because the fine grain size of the clay and silt that accumulate in this part of the lowlands (Bamory et al., 2007) ; (Pfeffer, 2011). As for the useful water content, it characterized the central zone due to the dominance of clay and fine silt which tend to retain water (Durand, 2003). 9 The glacis and hillsides were in difficult soil conditions than the central zone. Organic matter and mineral elements were carried away by the water towards the central zone (Sambaré et al., 2010). The bulk density of soils was great on hillsides and glacis due to insufficient organic matter. Organic matter influences soil structure and texture (Hassine et al., 2008) ; (Pallo et al., 2009). Glacis and hillsides were cereal crops farms which enriched the soil with potassium. While, the central zone was used for rice fields, the straws of which are less rich in potassium (Ben Hassine, 2006). Finally, the great number of regenerating seedlings in glacis and hillsides, is due to zoochory. The animals that frequented the lowlands deposited the seeds of the plants. However, due to the difficult climatic conditions in this area, these seedlings cannot survive (Soulama, 2016).

Importance Value Index (IVI) assessed Ecological significance of the species (table 3). It provided a better understanding of the importance of species in a community. In the glacis, three species belonging to FabacaeMimosoideae family, represented $83.3 \%$ of the total IVI. These were Balanithes aegyptica, Acacia senegal and Faidherbia albida. In the hillsides, four species were remarkable with a total IVI equal to $37.84 \%$. There were Balanithes aegyptica, Acacia senegal ; Acacia nilotica and Faidherbia 
albida . These dry environment species (Mahamane et al., 2007) characterized lowlands glacis and hillsides. Therefore, hillsides had relative ecological characteristics close to glacis. Finally, in the central zones, the ecological dominant species were Acacia polyacantha, Mitragyna inermis, Diospyros mespiliformis and Anogeiossus leocarpa. These wetland species (Mahamane et al., 2007) ;(Sambaré et al., 2010) ; (Kaboré et al., 2013) represented 59.32\% of the total of IVI.

According to the Ramsar Convention, wetlands include areas of marsh, permanent or temporary water, including their adjacent shores (Ramsar, 2013). Wetlands vegetation includes semi-deciduous forests, woodlands and savannas located at the banks of rivers, streams, and semi-permanent water points. In the Sahelo-sudanian region, species that are commonly identified as being characteristic of wetlands were Anogeissus leiocarpa, Diospyros mespiliformis ; Mitragyna inermis ; Acacia polyacantha Willd ., Crateva adansonii DC and Terminalia macroptera (Konaté, 2000); (Kaboré et al., 2013). Thus, the central zone of Nakanbé-Dem lowlands showed a relative floristic balance compared to the adjacent zones. The dominant families in hillsides and glacis strata were zygophyllacae and Fabaceae-Mimozoideae. These plants were characterized by a higher degree of sclerophyllia (plants whose leaves turn into thorns to limit water loss due to drought). The abundance of these species was explained by their adaptability to degraded soils and climatic conditions and by low use by populations (Khoudia et al., 2014). The low representation of Rubiaceae and Caesalpiniaceae families in hillsides and glacis strata reflected the temporary nature of the moisture in these sites (Sambaré et al., 2010) ; ( Kaboré et al. 2013). In addition, the high number of herbaceous species in glacis and hillsides than central zone which was rich in woody species, was another indicator of degradation of these first two units. Previous studies have shown a correlation between the degradation of sites and their specific enrichment (Soulama et al., 2015) ;(Soulama, 2016). Given the Sahelo-sudanian context where the pressure of livestock on wetlands was high, these biological indicators suggested that grazing pressure was one of the major factors in lowland's degradation. Indeed, grazing caused specific enrichment by importing seeds of herbs or primed woody species (Soulama et al., 2015).

Plant communities located in hillsides and glacis losed wetland specific flora and were more degraded than the ones located in central zone. In these strata flood duration was shorter than lowlands central zone (Sambaré et al., 2010) ;(Sambaré et al., 2011).

The natural regeneration of Sahelian glacis was highly dependent on soil surface conditions, microtopography and various anthropogenic activities (Kröpfl et al., 2013). Lowlands plants were affected by the combined effects of stress and disturbance due to climatic hazards and 
overgrazing. These factors have had significant negative effects on species growth and development on the Sahelian glacis.

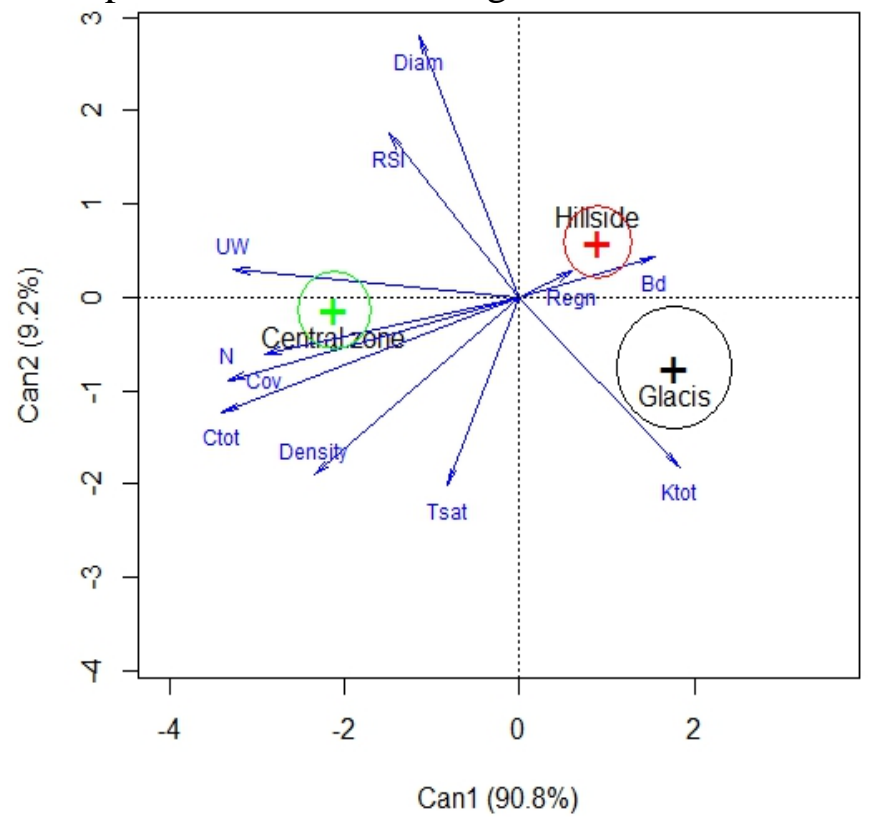

Figure 5: canonical discriminant analysis of the effect of topography on vegetation and soil parameters

Legend: $\operatorname{Cov}=$ Woody cover $; \boldsymbol{R e g n}=$ Density of regeneratin individuals; Density $=$ tree density; Diam = Quadratic diameter $\boldsymbol{R S I}=$ Ligneous plants species richness; $\boldsymbol{R S h}=$ Herbaceous species richness; $\mathbf{P F}=$ Useful water contents; $\mathbf{T}$ sat $=$ Saturation rate; $\boldsymbol{p H e}=$ potential Hydrogen in water; Pass = assimilable phosphorus; Ctot $=$ Total Carbon; $\boldsymbol{N}=$ Nitrogen; Ktot $=$ Total potassium; $\mathbf{B d}=$ Bulk density. 
Table 3: Ecological importance of Nakanbé-Dem lowlands species

\begin{tabular}{lcccc}
\hline \multicolumn{1}{c}{ Species } & \multicolumn{2}{c}{ Importance value Index (IVI) } & Family \\
& Glacis & Hillsides & Central zone & \\
\hline Acacia laeta R. Br. ex Benth. & 8,00 & - & - & Fabaceae-Mimosoideae \\
Acacia nilotica (L.) Willd. ex. Del. & - & 22,16 & - & Fabaceae-Mimosoideae \\
Acacia polyacantha Willd & - & - & 48,44 & Fabaceae-Mimosoideae \\
Acacia senegal (L.) Willd. & 46,41 & 24,21 & - & Fabaceae-Mimosoideae \\
Acacia senegalensis (L.) Willd & & 14,53 & - & Fabaceae-Mimosoideae \\
Acacia seyal Del. & 16,17 & 13,66 & 17,74 & Fabaceae-Mimosoideae \\
Acacia sieberiana DC. & - & - & 13,18 & Fabaceae-Mimosoideae \\
Adansonia digitata L. & - & 18,25 & - & Fabaceae-Mimosoideae \\
Anogeissus leiocarpa (DC.) Guill. et Perr. & - & 14,17 & 25,48 & Poaceae \\
Azadirachta indica A. Juss. & 15,32 & 18,95 & 11,61 & Meliaceae \\
Balanites aegyptiaca (L.) Del. & 176,41 & 36,15 & 8,14 & Zygophyllaceae \\
Bombax costatum Pellegr. et Vuillet. & 11,5 & 7,98 & - & Malvaceae \\
Boscia angustifolia A. Rich. & - & 6,96 & - & Capparaceae \\
Combretum micranthum G. Don. & - & 4,6 & 8,16 & Combretaceae \\
Diospyros mespiliformis Hochst. ex A. DC. & - & 16,49 & 36,34 & Ebenaceae \\
Faidherbia albida (Delile) A.Chev. & 26,19 & 21,01 & 4,04 & Fabaceae-Mimosoideae \\
Ficus sycomorus L. & - & - & 6,88 & Malvaceae \\
Khaya senegalensis (Desr.) A. Juss. & - & 2,99 & 9,73 & Meliaceae \\
Lannea microcarpa Engl. et K. Krause & - & 5,4 & 4,17 & Anacardiaceae \\
Mitragyna inermis (Willd.) Kuntze & - & 16,19 & 67,72 & Rubiaceae \\
Piliostigma reticulatum (DC.) Hochst. & - & 5,27 & 14,68 & Fabaceae-Caesalpinioideae \\
Sclerocarya birrea (A. Rich.) Hochst & - & 18,47 & 3,01 & Anacardiaceae \\
Stereospermum kunthianum Cham. & - & 2,53 & - & Bignoniaceae \\
Tamarindus indica L. & - & 4,93 & 3,65 & Fabaceae-Caesalpinioideae \\
Vitellaria paradoxa Gaertn. f. & - & 20,17 & 17,03 & Sapotaceae \\
Ziziphus mauritiana Lam. & - & 4,92 & - & Rhamnaceae \\
TOTAL & 300 & 300 & 300 & \\
\hline & & & &
\end{tabular}

The Nakanbé-Dem watershed has shown precipitation decrease in and anthropogenic pressures over the past decades (Thiombiano, 2000). The analysis of spatio-temporal dynamics allowed to perceive that the evolution of the socio-economic and biophysical factors of Nakanbé-Dem expose the lowlands potential to the accelerated degradation risks. The strong trend of population increase in the Center-Nord region (DREP / CN, 2017) will lead, over the next decades, to an intensification of the conquest of new productive lands. This growing demographic pressure often combined with inappropriate agricultural practices, including slash-and-burn, logging of trees for charcoal and obtaining firewood (Oloukoi et al., 2006). Such a context increases the deterioration risk of lowlands potential. In the coming decades, if the demographic and climatic factors continue in Nakanbé-Dem, the rate of decline in riparian formation could increase and lead to their disappearance. The lowland beds will experience the same tendency to spatial reduction. This, in view of the grazing persistence and agricultural land clearing, which has accelerate the degradation of low-land (Thiombiano, 2000). This deterioration of the lowland beds will be accompanied by an extension of the areas of crop fields (Ibrahim, 2013). In view of the strong growing land pressure in Nakanbé-Dem (DREP/CN, 2017), this extension rate of farming could be higher in the coming years. Above all, when the 
persistence of bad climatic conditions in the Sahelian zone of Africa is expected to worsen in the coming decades (Pana, 2003). Correlatively therefore to the climatic deterioration, the filling rates of the reservoirs will be poor. The spatio-temporal variability of the climate, the improper management of the soil will continue to accentuate the risk of weakening of the lowlands potential in the Nakanbé-Dem. To mitigate this risk in the coming years, it will be necessary to:

- build the capacity of lowland farmers in techniques of restoring lowland ecosystems;

- set up lowland management units involving operators, technical services of the State, NGOs and associations;

- sevelop and implement a manual of dreariest and techniques for the protection of the Sudano-Sahelian lowland.

\section{Conclusion}

Lowlands' potential listed represents 43320 ha or $26.25 \%$ of the Nakanbé-Dem sub-watershed (165029 ha). It composed by all the lowlands with an area more than 0.5 ha and whose slope was less than or equal to $2 \%$. Occupation units of lowlands' potential in the Nakanbé -Dem knew a spatial dynamic of degradation between 1986 and 2016. In addition, ecological and pedological indicators indicated that degradation is less pronounced in the central areas of the lowlands that on glacis and hillsides. The persistence of poor rainfall, the increase in the population and the bad soil management risk accelerating the degradation dynamics of the lowlands' potential in the Nakanbé-Dem. The results of the ecological and pedological analysis will guide the implementation of restoration actions which will be better adapted to the topography and to occupation units of lowland' potential. The lowland potential map produced is an instrument to help the geographic location of areas with high agricultural potential. Understanding the spatial dynamics of the lowland' potential will allow to take this into account in the development and implementation of programs to protect degraded ecosystems in the Nakanbé-Dem lowlands.

\section{Aknowledgements}

Nakanbé Water Agency (NWA) and the Permanent Secretariat for Integrated Water Resources Management (SP / IWRM) are gratefully thanks for their contributions to this work.

\section{References:}

1. AL-Awadhi, O, S.. \& R.F., M. (2004). Land degradation indicators in Kuwait. Land degradation \& Development, 16, 163-176. 
2. Andriesse, W., Fresco, L., Duivenboode, N., Windmeijer, P. (1994). Multi-scale characterization of inland valleya gro-ecosystems in West Africa. netherlands Journal of Agricultural Science, 159-179.

3. Anyamba, A. \& Tucker, C.J. (2005). Analysis of Sahelian vegetation dynamics using NOAA-AVHRR NDVI data from 1981-2003. Journal of Arid Environments, 63, 596-614.

4. Ariori, S.L. \& Ozer, P. (2005). Evolution des ressources forestières en Afrique de l'Ouest soudano-sahélienne au cours des 50 dernières années Trends in Soudano-Sahelian West African extent of forest during the second half of the 20th century. Geo-Eco-Trop, 29, 61-68.

5. Bambara, D., Bilgo, A., Hien, E., Masse, D., Thiombiano, A., Hien, V. (2013). Perceptions paysannes des changements climatiques et leurs conséquences socio environnementales à Tougou et Donsin, climats sahélien et sahélo-soudanien du Burkina Faso. Bulletin de la Recherche Agronomique du Bénin (BRAB), 74, 16.

6. Bamory, K., Luc, S., Guillaume, F., Jean-Luc, S., Marc, D., Pascal, A. (2007). Processus et bilan des flux hydriques d'un bassin versant de milieu tropical de socle au Bénin (Donga, haut Ouéme'). ScienceDirect, 339, 418-429.

7. Bandré, E. \& Da, D.E.C. (2004). Impact de la dynamique du couvert végétal sur l'ensablement du lac Dem au Burkina Faso. Priorités et pratiques du développement rural en Afrique subsaharienne, 135-148.

8. Bigot, S., Isabelle, Z., Diedhiou, A. (2005). Apport de données de HRV de SPOT pour l'étude des variations phénologiques dans le bassin de l’Ouémé (Bénin). Télédétection, 4, 339-353.

9. Chabi, A., Oloukoi, J., Mama, V.J., Kiepe, P. (2010). Inventaire par télédétection des agro-écosystèmes de bas-fonds dans le centre du Bénin. Cahiers Agricultures, 19, 446-453.

10. CPCS. (1967). Commission de pédologie et de cartographie des sols. Paris: Ensa- Grignon.

11. Collado, A.D., Chuvieco, E. Camarasa, A. (2002). Satellite remote sensing analysis to monitor desertification processes in the croprangeland boundary of Argentina. Journal of Arid Environments, 52, 121-133.

12. CR-CN. (2015). Plan régional de développement du Centre-Nord 2015-2019. 
13. Da, D., Yacouba, H., Yonkeu, S. (2008). Unités morphopédologiques et gestion de la fertilité des sols dans le Centre-Nord du Burkina Faso par les populations locales. International Journal of Biological and Chemical Sciences, 2, 306-315.

14. Diouf, A. \& Lambin, E.F. (2001). Monitoring land-cover changes in semi-arid regions: remote sensing data and field observations in the Ferlo, Senegal. Journal of Arid Environments, 48, 129-148.

15. Dlamini, P., Chivenge, P., Manson, A., Haplot, V. (2014). Land degradation impact on soil organic carbon and nitrogen stocks of subtropical humid grasslands in South Africa. Geoderma, 372-381, 235236.

16. DREP/CN. (2017). Profil régional 2017 du centre-Nord. Kaya.

17. Durand, M.C. (2003). Caractérisation physico-chimique des produits de l'assainissement pluvial. Origine et devenir des métax traces et des polluants organiques. Thèse de doctorat. Université de Poitiers.

18. Fontès, J. \& Guinko, S. (1995). Carte de végétation et de l'occupation d'un sol du Burkina Faso. Notice explicative. Université de Ouagadougou., 67, (881-3101).

19. Gao, B. (1996). NDWI A Normalized Difference Water Index for Remote Sensing of Vegetation Liquid Water From Space. Remote sens. Environ., 266, 257-266.

20. Geymen, A. \& Baz, I. (2008). Monitoring urban growth and detecting land-cover changes on the Istanbul metropolitan area. Environmental Monitoring and Assessment, 136, 449-459.

21. Hamma, Y., Dapola Evariste, D., Samuel, Y. (2000). Caracterisation du ruissellement et de l'érosion hydrique dans le bassin superieur du Nakambe (Burkina Faso). Ecole Inter-Etats d'Ingénieur de l'Equipement Rural, Envirowale, 8.

22. Hassine, H. Ben. (2006). Nature minéralogique et rôle nutritionnel des argiles de sols céréaliers en région subhumide à semi-aride (Tunisie). Comptes Rendus - Geoscience, 338, 329-340.

23. Hassine, H., Aloui, T., Gallali, T., Bouzid, T., Amri, S.E.L., Ben, R. (2008). Évaluation quantitative et rôles de la matière organique dans les sols cultivés en zones subhumides et semi-arides méditerranéennes de la Tunisie. Agrosolutions, 19, 2. 
24. Hountondji, Y.-C. (2008). Dynamique environnementale en zones sahélienne et soudanienne de l'Afrique de l'Ouest: Analyse des modifications et évaluation de la dégradation du couvert végétal. Faculté des Sciences, Département des Sciences et Gestion de l'Environnement.

25. Ibrahim, B. (2013). Caractérisation des saisons de pluies au Burkina Faso dans un contexte de changement climatique et évaluation des impacts hydrologiques sur le bassin du Nakanbé.

26. INSD. (2009). Projections démographiques de 2007 à 20120. Ouagadougou.

27. Kaboré, E., Sambaré, O., Ouédraogo, A. \& Thiombiano, A. (2013). Diversité et structure des cordons ripicoles le long de la sirba ( NordEst du Burkina Faso ). Int. J. Biol. Chem. Sci., 7, 1929-1950.

28. Kaplan, G. \& Avdan, U. (2017). European Journal of Remote Sensing Object-based water body extraction model using Sentinel-2 satellite imagery. European Journal of Remote Sensing, 50, 137-143.

29. Khoudia, N., Ndiaye, O., Diallo, A., Guisse, A. (2014). Flore et structure de la végétation ligneuse le long de la Grande Muraille Verte au Ferlo , Nord Sénégal. Journal of Applied Biosciences, 79, 6938 6946. http://dx.doi.org/10.4314/jab.v79i1.15.

30. Konaté, L. (2000). Les bas-fonds dans le réseau hydrographique du fleuve Gambie. Thèse. Univsersité Cheikh Anta Diop de Dakar. Département de Géographie.

31. Kröpfl, A.., Cecchi, G.A., Villasuso, N., Distel, R.. (2013). Degradation and recovery processes in semi-arid patchy rangelands of northern patagonia, Argentina. Land Degradation \& Development, 24, 393-399.

32. Mahamane, A., Mahamane, S., Yacouba, B., Issaka, A., Ichaou, A., Saley, K. (2007). Analyse diachronique de l'occupation des terres et caractéristiques de la végétation dans la commune de Gabi (région de Maradi, Niger). Sécheresse, 18, 296-304. DOI: 10.1684/sec.2007.0105.

33. MEE. (2001). État des lieux des ressources en eau du Burkina Faso et de leur cadre de gestion. Burkina Faso.

34. MR-CN. (2011). Enquête nationale sur l'accès des ménages aux ouvrages d'assainissement familial - 2010. 
35. Nébié, O. (2018). Les aménagements hydro-agricoles au Burkina Faso : Analyse et bilan critiques. Travaux de l'Institut Géographique de Reims, 123-140.

36. Niang, D. (2006). Fonctionnement hydrique de differents placages sableux dans le Sahel Burkinabe.

37. Oloukoi, J., Mama, V.J., Fulbert, E., Agbo, B. (2006). Modélisation de la dynamique d'occupation des terres dans le département des collines au Bénin. Télédétection, 6, 305-323. https://www.researchgate.net/publication/279851907.

38. Oszwald, J., Antoine, L., Arnauld de Sartre, X., Marcello, T., Gond, V., others. (2010). Analyse des directions de changement des états de surface végétaux taux pour renseigner la dynamique du front pionnier Maçaranduba(PARA, BRÉSIL) ENTRE 1997 ET 2006. Revue Télédétection, 9, 97-111.

39. Oszwald, J., Kouacou Atta, J.-M., Kergomard, C., Robin, M. (2007). Représenter l'espace pour structurer le temps: Approche des dynamiques de changements forestiers dans le sud-est de la Côte d’Ivoire par télédetection. Revue Télédétection, vol. 7, n 1-2-3-4, 271-282.

40. Ouédraogo, A. (2006). Diversité et dynamique de la végétation ligneuse de la partie orientale du Burkidurna Faso. Thèse de Doctorat. Université de Ouagadougou.

41. Ouédraogo, F. \& Hottin, G. (1992). Carte géologique du Burkina Faso. Echelle 1:1000 000 + notice explicative. Ouagadougou.

42. Ouédraogo, M., Youssouf, D., Somé, L. (2010). Perceptions et stratégies d'adaptation aux changements des précipitations : cas des paysans du Burkina Faso. Sécheresse, 21, 169-78.

43. Pana. (2003). Synthèse des études de vulnérabilité et d'adaptation aux changements climatiques :étude de cas du Burkina Faso.

44. Pfeffer, J. (2011). Etude du cycle de l'eau en Afrique sahélienne: Approche multidisciplinaire et apport de la gravimétrie terrestre et spatiale. Thèse de doctorat. Université de Strasbourg.

45. Pierre, D. (2007). Interrelations Climat-Homme-Environnement dans le Sahel Burkinabé : impacts sur les états de surface et la modélisation hydrologique .

46. Ramsar. (2013). Le manuel de la Convention de Ramsar, Gème édition. 
47. Robert, E. (2011). Les risques de pertes en terre et en eau dans le bassin versant de la Doubégué (Burkina Faso) : pour une gestion intégrée. Thèse de Doctorat. niversité Michel de Montaigne -Bordeaux3.

48. Salovaara, K.J., Thessler, S., Malik, R.N., Tuomisto, H. (2005). Classification of Amazonian primary rain forest vegetation using Landsat ETM+ satellite imagery. Remote Sensing of Environment, 39-51.

49. Sambaré, O., Bognounou, F., Wittig, R., Thiombiano, A. (2011). Woody species composition, diversity and structure of riparian forests of four watercourses types in Burkina Faso. Journal of Forestry Research, 22, 145-158.

50. Sambaré, O., Ouédraogo, O., Wittig, R., Thiombiano, A. (2010). Diversité et écologie des groupements ligneux des cordons ripicoles du Burkina Faso (Afrique de l’Ouest). Int J Biol Chem Sc, 4, 17821800.

51. Souberou, K., Agbossou, K.E., Ogouwale, E. (2017). Inventaire et caractérisation des bas-fonds dans le bassin versant de l'Oti au Bénin à l'aide des images Landsat et ASTER DEM. International Journal of Environment, Agriculture and Biotechnology (IJEAB), 2, 1601-1623. http://dx.doi.org/10.22161/ijeab/2.4.20.

52. Souberou, K., Oloukoi, J., Amoussou, E. (2016). Cartographie du potentiel en bas-fonds aménageables de la commune de Matéri au Bénin. Revue de Géographie de l’Université Ouaga I Pr Joseph KIZERBO, 2, 1-27.

53. Souberou, K.T., Barre, I.O., Yabi, I., Ogouwale, E. (2018). Fondements géographiques de la valorisation agricole des bas-fonds au Sud du bassin versant de l'Oti (Bénin). European Scientific Journal, ESJ, 14, 1601-1623.

54. Soulama, S. (2016). Types d'utilisation des terres et incateurs de dégradation de la biodiversité dans les réserves de Pama et les agrosystèmes ( Sud-est du Burkina Faso). Université Joseph KI ZERBO.

55. Soulama, S., Kadeba, A., Nacoulma, B., Traore, S., Bachmann, Y., Thiombiano, A. (2015). Impact des activités anthropiques sur la dynamique de la végétation de la réserve partielle de faune de Pama et de ses périphéries (sud-est du Burkina Faso) dans un contexte de 
variabilité climatique. Journal of Applied Biosciences, 87, 8047. DOI: http://www.globalscienceresearchjournals.org/

56. SP/CONEDD. (2003). Synthèse des études de vulnérabilité et d'adaptation aux changements climatiques : étude de cas du Burkina Faso. Ouagadougou.

57. Thiombiano, L. (2000). Etude de l'importance des facteurs édaphiques et pédopaysagiques dans le développement de la désertification en zone sahélienne du Burkina Faso. Thèse de Doctorat d'Etat.Université de Ouagadougou.

58. Traoré, S., Ouattara, K., Ilstedt, U., M., S., A., T., A., M., G., N. (2015). Effect of land degradation on carbon and nitrogen pools in two soil types of a semi-arid landscape in West Africa. Geoderma, 330-338.

59. Yoshida, H. (2005). Observation of riparian vegetation in western Namibia by using NDVI and NDWI derived from. Departmental Bulletin Paper/ Kyoto university, 153-163. 